\title{
LOSS OF TREE BIOMASS IN JURE LANDSLIDE, SINDHUPALCHOWK, NEPAL
}

Smrita Acharya and Udhab Raj Khadka

Journal of Institute of Science and Technology

Volume 21, Issue 1, August 2016

ISSN: 2469-9062 (print), 2467-9240(e)

Editors:

Prof. Dr. Kumar Sapkota

Prof. Dr. Armila Rajbhandari

Assoc. Prof. Dr. Gopi Chandra Kaphle

JIST, 21 (1), 65-70 (2016)

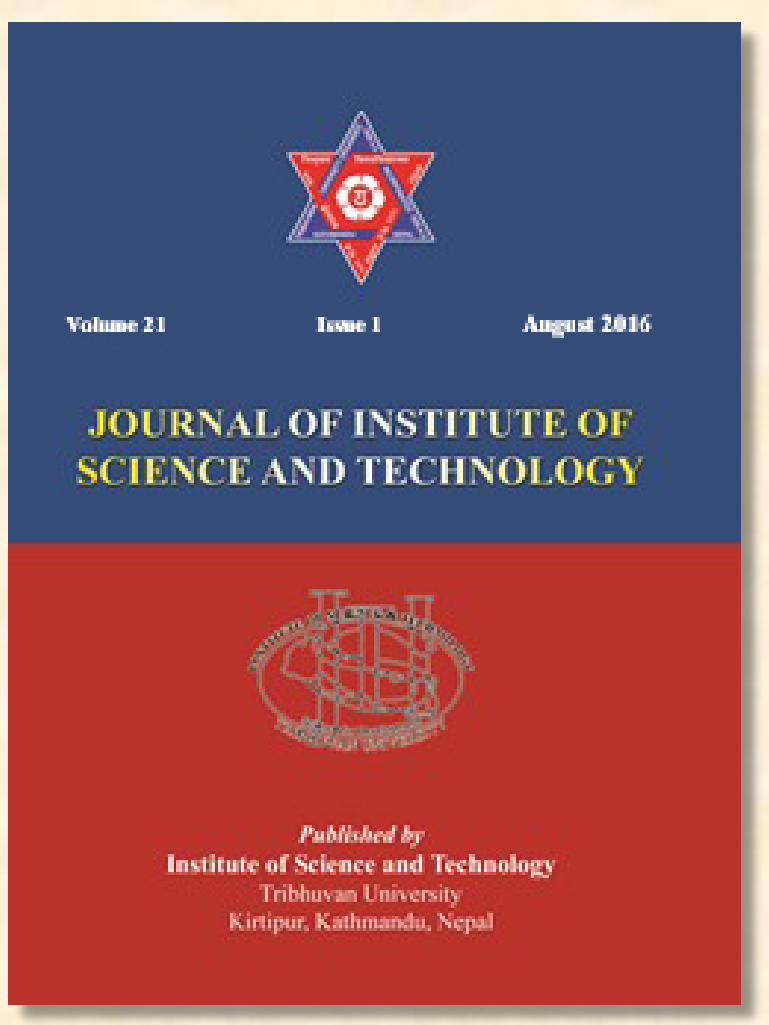

Published by:

Institute of Science and Technology

Tribhuvan University

Kirtipur, Kathmandu, Nepal 


\title{
LOSS OF TREE BIOMASS IN JURE LANDSLIDE, SINDHUPALCHOWK, NEPAL
}

\author{
Smrita Acharya ${ }^{1}$ and Udhab Raj Khadka, ${ }^{1,2 *}$ \\ ${ }^{1}$ Central Department of Environmental Science, Tribhuvan University, Kathmandu, Nepal \\ ${ }^{2}$ Department of Botany, Amrit Science Campus, Tribhuvan University, Kathmandu, Nepal \\ *Corresponding email: ukhadka@cdes.edu.np
}

\begin{abstract}
Landslide causes massive loss of lives and properties along with intangible losses in mountainous regions. Yet such intangible losses in ecosystems are rarely considered. The present study assesses the tree biomass lost due to Jure landslide in Sindhupalchowk that destroyed 71 hectare of land. Altogether, 12 plots $\left(250 \mathrm{~m}^{2}\right)$ were sampled through systematic and purposive sampling technique. The total tree biomass was estimated using allometric equation. The study recorded 21 tree species in which Schimawallichiii (Korth.), Lagerstroemia parviflora (Roxb.), Shorea robusta (Gaertn.), Alnus nepalensis (D. Don), Phyllanthus emblica (Linn.) and Celtius australis (Linn.) were dominant. Schima wallichiii had the highest density (320 individual ha ${ }^{-1}$ ) and frequency (92\%). The total biomass of tree species was 216 ton ha ${ }^{-1}$ in which Schima wallichiii constituted the highest total tree biomass $\left(82\right.$ ton ha $\left.{ }^{-1}\right)$. In 71 ha landslide area, the landslide caused loss of 15,336 tons of total tree biomass, which equals to 56,283 tons $\mathrm{CO}_{2}$ equivalents. These findings are relevant for assessing post-landslide impacts on the mountain environment. Furthermore, to reduce carbon emissions resulting from forest loss, mitigation of landslide is crucial.
\end{abstract}

Keywords: Biomass, Carbon emission, Density, Mitigation

\section{INTRODUCTION}

Nepal has very fragile topography. Three quarter of the total land area of Nepal is mountainous and many villages are situated on or adjacent to the unstable hill slopes. The landslide and flood with debris flow result in severe damages. Each year such types of disasters cause the losses of a number of human lives and immense damages to agricultural land, crops, human settlements and other physical properties (MoHA and DPNeT 2015). Landslide causes changes in terrain, increases sediment load, vertical displacement of ground and can initiate further erosion leading to wide spread land degradation. During such events, forests resources are also swept down causing loss of forest ecosystem. The carbon reservoir in the world's forest is higher than in the atmosphere (Stern, 2007). Forest acts as both carbon sink and source. For all the species of tree, an average 50\% of the biomass is estimated as carbon content (MacDicken, 1997). It is well known fact that carbon sequestration by growing forest has been shown to be cost effective option for mitigating global climate change. However, according to World Bank report (2010), deforestation and forest degradation are responsible for about $20 \%$ of anthropogenic
GHGs emissions, a major issue for climate change negotiation. Hence, forest as a source or sink largely depends on succession stage, specific disturbance or management intervention (Masera et al., 2003). Forest destruction due to natural disasters like landslide, flood, hurricane etc. produces decaying dead wood which like any decaying matter is a transient $\mathrm{C}$ pool. Natural disasters could significantly diminish the terrestrial carbon sink. A study by Chambers et al. (2007) on carbon footprint due to hurricane Katrina on Gulf coast forest showed that a total biomass loss of 105 $\operatorname{TgC}(1,05,000,000$ tons) was incurred. Similarly, Restrepo et al. (2003)'s research about influence of landslide on distribution of biomass in Hawaii, showed irreversible transformation of Ninole ecosystem within last 430 years with landslide disturbance rate, $15 \%$ per century, equivalent to 53 ton $\mathrm{ha}^{-1}$ biomass per century to exit through the system. In Nepal, the nationwide landslide inventory of 2015 had reported 5,003 landslides with total area of $126.34 \mathrm{~km}^{2}$ (CDES-TU, 2015). In open and dense forest type, 1,159 and 779 landslides were observed which accounted to 33.20 $\mathrm{km}^{2}$ and $15.60 \mathrm{~km}^{2}$ area, respectively. In these landslide areas substantial amount of biomass loss 
has occurred. However, in Nepal, preceding studies about such losses seems to be seldom. Therefore, the present study was carried out with an aim of determining tree biomass lost due to Jure landslide in Sindhupalchowk.

\section{MATERIALS AND METHODS}

\section{Study area}

Sindhupalchowk district lies in the Bagmati zone of central development region, with an area of 2,542 $\mathrm{km}^{2}$. The district's headquarters, Chautara, is 120 $\mathrm{km}$ east of Kathmandu. The landslide occurred in Jure village of Sindhupalchowk, on $2^{\text {nd }}$ August 2014, near boundary of Mangkha and Ramche Village Development Committee (VDC) (Fig. 1). It is situated at $27^{\circ} 45^{\prime} 55.36^{\prime \prime} \mathrm{N}$ latitude and $85^{\circ} 52^{\prime 25.95 " ~ E ~ l o n g i t u d e, ~ a t ~ a n ~ e l e v a t i o n ~ o f ~} 841 \mathrm{~m}$ above sea level. The landslide was $1.26 \mathrm{~km}$ in length and $0.71 \mathrm{~km}^{2}$ (71 hectare) in area (ICIMOD, 2014) that had dammed the Sunkoshi River. It perched $1,350 \mathrm{~m}$ above the river bed which collapsed resulting in a loss of 156 human lives and property worth of 130.4 million (MoHA \& DPNeT, 2014). A total of 478 families were affected from that unfortunate event (NDR, 2015). Around one fourth of the Bagane Khaho community forest (38 ha) with major tree species Schima wallichiii, Alnus nepalensis and Shorea robusta was destroyed due to the landslide in the study area. The Jure landslide was a typical rock avalanche or slope failure type of mass movement. The rock types in the landslide area are phyllite, schist and quartzite (MoI 2014). The area was reported hazard prone, since landslide slip was recorded earlier in 2007 (ICIMOD, 2014).

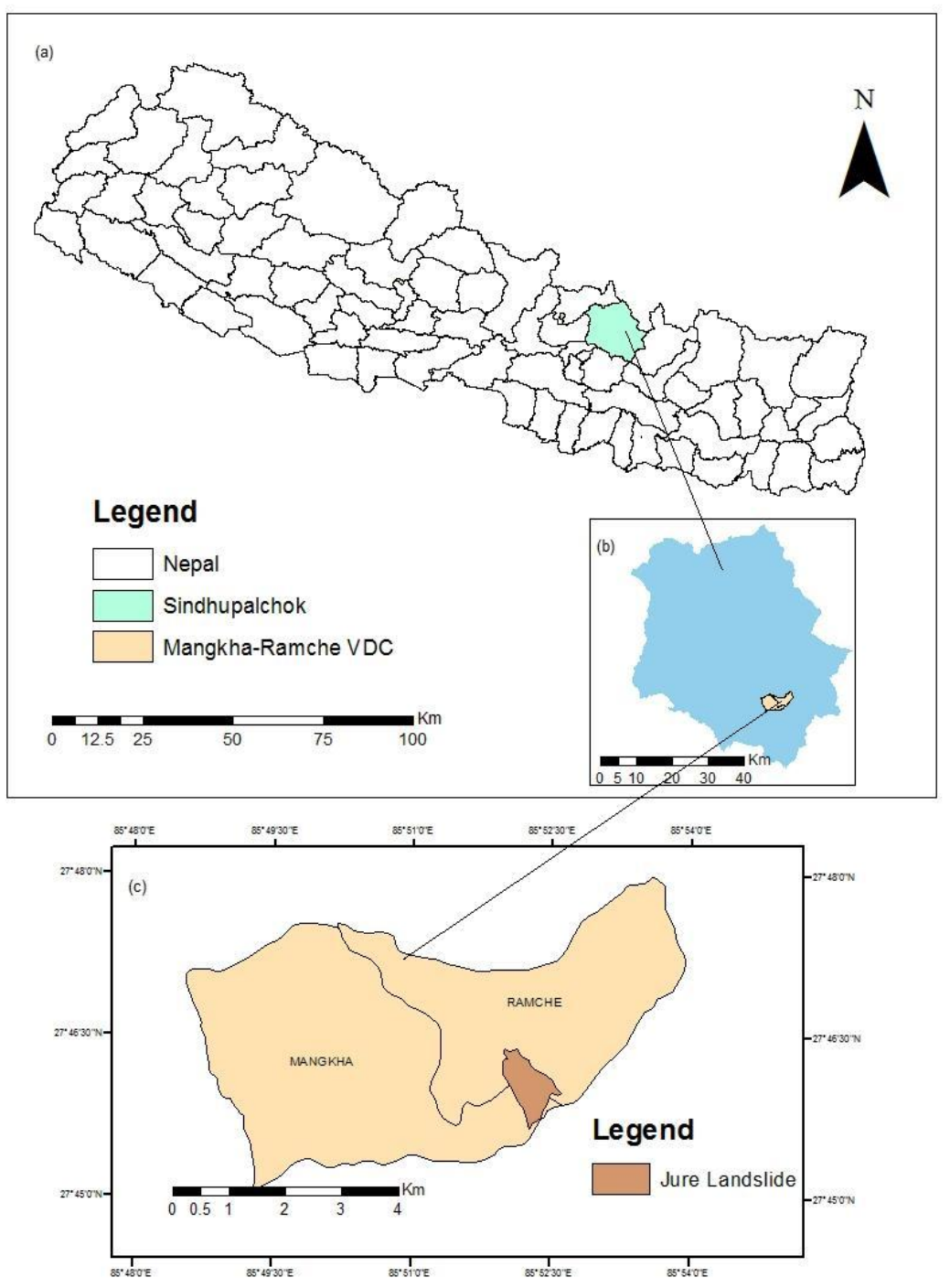

Fig. 1: Map of study area showing (a) location, (b) Sindhupalchowk district, (c) Mangkha and Ramche VDC. 


\section{METHODS}

In order to assess biomass loss, a field study was carried out during October 2014, within $2 \mathrm{~km}$ periphery along the immediate vicinity of the Jure landslide area. A systematic and purposive sampling technique was used to collect tree species data through transect walk on the east and west side (Fig. 2). A total of 12 circular plots (radius: $8.92 \mathrm{~m}$, area: $250 \mathrm{~m}^{2}$ ) were sampled from $900 \mathrm{~m}$ to $1500 \mathrm{~m}$ elevation.

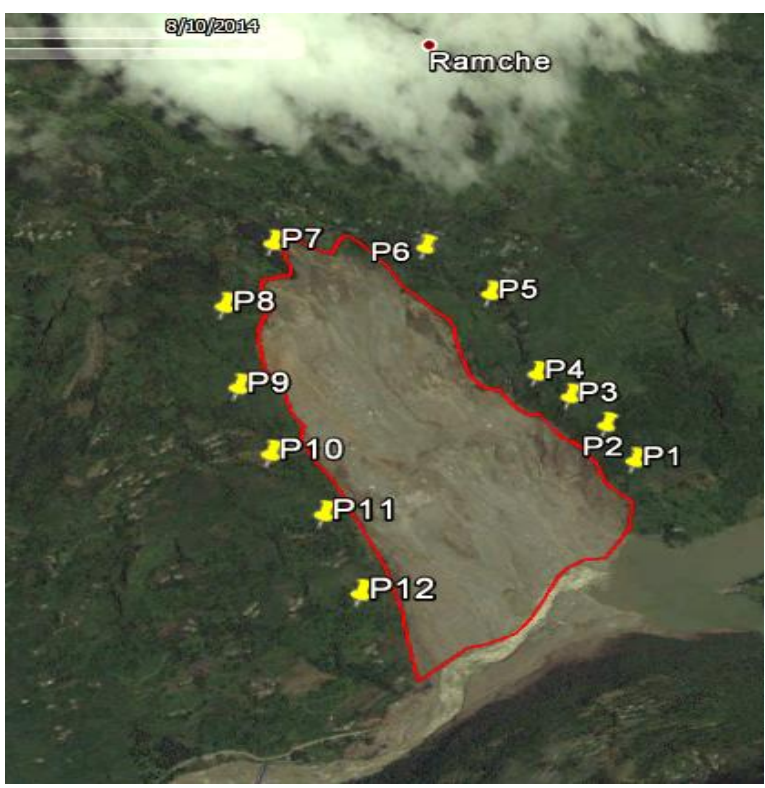

Fig. 2: Sampling plots along vicinity of Jure landslide area (Source: Google Earth Imagery - 8th October, 2014).

In each plot, the height and DBH $(\geq 5 \mathrm{~cm})$ of the individual of every tree species were measured using vortex and measuring tape, respectively (Subedi et al., 2010). The common names of tree species in the field were noted through local consultation and later identified using standard references (Shrestha, 1998; Bista et al., 2001). The collected data were analyzed to obtain density and frequency, following Zobel et al. (1987). The biomass of tree species above ground was estimated using allometric equation developed by Chave et al. (2005) for moist forest (annual precipitation 1500 mm-3500 mm) (Eq. 1).

$A G T B=0.0509 \times \rho \pi D^{2} H$

Where, $\mathrm{AGTB}=$ Above ground tree biomass $(\mathrm{kg})$ and $\rho=$ Wood density $\left(\mathrm{kg} \mathrm{m}^{-3}\right)$

$\mathrm{H}=$ Height of tree $(\mathrm{m})$

$\mathrm{D}=$ Diameter of tree at breast height $(\mathrm{m})$
The wood density of each tree species was obtained from forest carbon inventory (MoFSC, 2010). For tree species with unavailable density values, the mean value of the density of other species belonging to the same genus or family was used, referring to Brown et al. (1989) (Eq. 2).

$Y=\exp .(-3.1142+0.9719) \ln \left(D^{2} H\right)$

Where, $\mathrm{Y}=$ Wood density of the tree

$\mathrm{D}=$ Diameter $(\mathrm{cm})$

$\mathrm{H}=$ Height $(\mathrm{m})$

The root-to-shoot ratio value of 1:5 was used for below ground biomass calculation, i.e. equals to $20 \%$ of above-ground tree biomass following MacDicken (1997). The summation of above and below ground biomass was done to obtain total tree biomass. The total tree biomass was then converted to tons of $\mathrm{CO}_{2}$ equivalent as given by Pearson et al. (2007). The total tree biomass lost due to landslide was then obtained indirectly.

\section{RESULTS}

\section{Density and frequency of tree species}

Altogether, 21 tree species of mid-hill mixed forest like Schima wallichiii, Alnus nepalensis, Terminalia tomentosa, Shorea robusta, Phyllanthus emblica etc., were observed in the sampled plots (Table 1). Among the tree species, Schima wallichiii was found in all sampled plots with highest density (320 individual ha ${ }^{-1}$ ) and frequency (92\%). The species like Lagerstroemia parviflora, Alnus nepalensis, Shorea robusta, Phyllanthus emblica and Celtis australis were the other major tree species with higher density (Fig. 3). The tree species such as Albizia chinensis, Choreospondias axillaris, Garuga pinnata and Lannea sp. were the species with lowest density ( 3 individual $\mathrm{ha}^{-1}$ ).

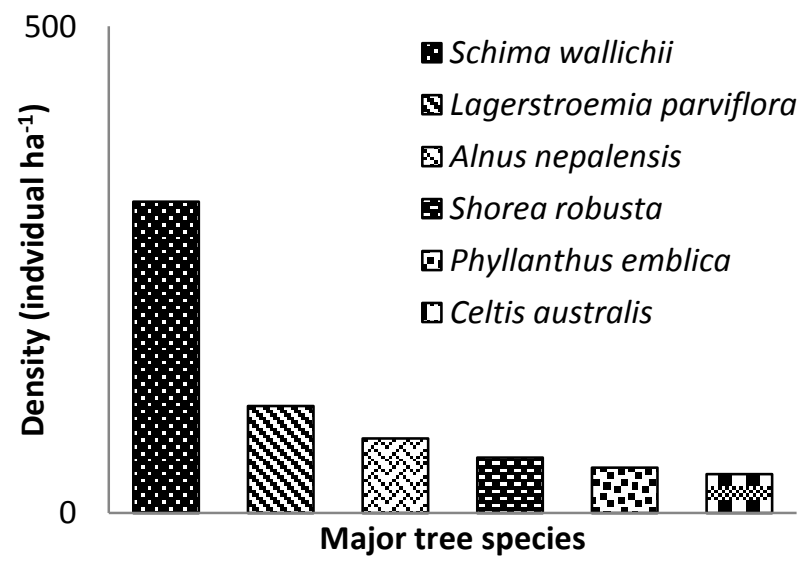

Fig. 3: Density of major tree species. 


\section{Total tree biomass}

The mean above and below ground tree biomass was found to be 180 tons ha ${ }^{-1}$ and 36 tons ha ${ }^{-1}$, respectively with mean total tree biomass 216 tons $\mathrm{ha}^{-1}$. Among the species, the highest total tree biomass was constituted by Schima wallichiii (82 ton $\mathrm{ha}^{-1}$ ) followed by Alnus nepalensis (71 ton $\left.\mathrm{ha}^{-1}\right)$, Lagerstroemia parviflora $\left(16\right.$ ton $\left.\mathrm{ha}^{-1}\right)$, Shorea robusta (15 ton ha $\left.{ }^{-1}\right)$, Celtis australis (3 ton $\left.\mathrm{ha}^{-1}\right)$ and Phyllanthus emblica ( 3 ton $\mathrm{ha}^{-1}$ ) (Fig. 4).

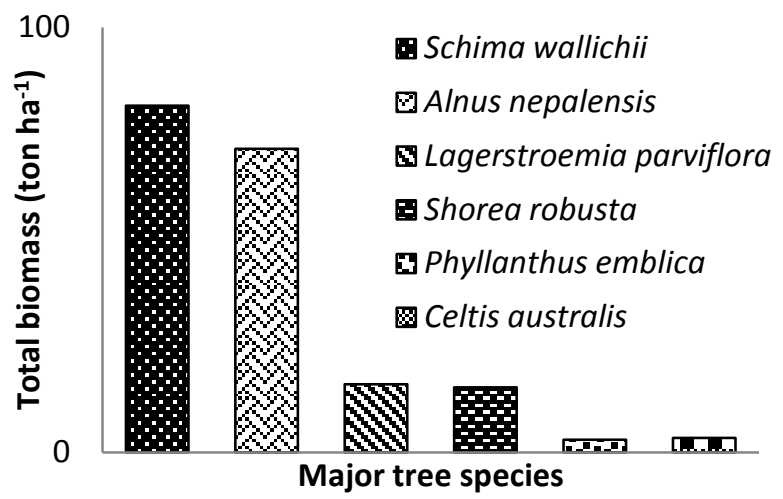

Fig. 4: Total biomass of major tree species.

Table 1: Density and frequency of tree species

\begin{tabular}{|c|c|c|c|}
\hline S.N. & Name of species & $\begin{array}{c}\text { Density } \\
{\text { (individual } \mathrm{ha}^{-1} \text { ) }}\end{array}$ & Frequency $(\%)$ \\
\hline 1. & Schima wallichiii (Korth.) & 320 & 92 \\
\hline 2. & Oroxylum indicum (Linn.) & 7 & 8 \\
\hline 3. & Lagerstroemia parviflora (Roxb.) & 110 & 50 \\
\hline 4. & Cleistocalyx operculatus (Roxb.) Merr. \& Perry. & 17 & 33 \\
\hline 5. & Shorea robusta (Gaertn.) & 57 & 33 \\
\hline 6. & Cletis australis (Linn.) & 40 & 50 \\
\hline 7. & Albizia chinensis (Osbeck.) Merr. & 3 & 8 \\
\hline 8. & Bassia butyracea (Roxb.) Baehni. & 7 & 8 \\
\hline 9. & Phyllanthus emblica (Linn.) & 47 & 58 \\
\hline 10. & Anthocephalus chinensis (Lam.) A. Rich. & 13 & 8 \\
\hline 11. & Lannea sp. & 3 & 8 \\
\hline 12. & Symploeos chinensis (Lour.) & 10 & 8 \\
\hline 13. & Terminalia tomentosa (Roxb.) & 13 & 33 \\
\hline 14. & Spondias pinnata (L.f.) Kurz. & 3 & 8 \\
\hline 15. & Garuga pinnata (Roxb.) & 3 & 8 \\
\hline 16. & Marsdenia tenacissima (Roxb.) Moon. & 7 & 8 \\
\hline 17. & Choreospondias axillaris (Roxb.) B.L. Burtt \& A.W. Hill. & 3 & 8 \\
\hline 18. & Alnus nepalensis (D. Don) & 77 & 8 \\
\hline 19. & Litsea monopetala (Roxb.) ex Rotfl. \& Willd. & 37 & 33 \\
\hline 20. & Cedrela toona (Roxb.) & 20 & 33 \\
\hline 21. & Bombax cebia (Linn.) & 17 & 25 \\
\hline
\end{tabular}

\section{Total tree biomass loss}

The total tree biomass loss within 71 hectare landslide area was found to be 15,336 tons which is 56,283 tons of $\mathrm{CO}_{2}$ equivalents. The landslide largely destroyed Schima wallichiii (5,788 tons) and Alnus nepalensis (5068 tons). The biomass loss of other species like Lagerstroemia parviflora, Shorea robusta and Celtis australis together accounted to be 2,444 tons. 
Table 2: Total tree biomass

\begin{tabular}{lccc}
\hline & AGTB $\left(\right.$ ton $\left.\mathbf{~ h a}^{-\mathbf{1}}\right)$ & BGB $\left(\right.$ ton $\left.\mathbf{~ h a}^{-\mathbf{1}}\right)$ & Total Biomass $\left(\right.$ ton $\left.\mathbf{~ h a}^{\mathbf{- 1}}\right)$ \\
\hline Total & 2156 & 431 & 2587 \\
Average & 180 & 36 & 216 \\
\hline
\end{tabular}

\section{DISCUSSION}

The present study revealed that among the 21 tree species observed in the sampled plots, Schima wallichiii constitutes the species with highest density and frequency, followed by Lagerstroemia parviflora, Alnus nepalensis and Phyllanthus emblica. Pandey et al. (2010) reported Alnus nepalensis, Pinus roxburgii, Schima wallichii etc. species in Sikre VDC, Kathmandu within $831 \mathrm{~m}$ to $2426 \mathrm{~m}$ elevation range where highest density of Alnus nepalensis was found. This result supports present study.

The average total tree biomass (216 tons $\mathrm{ha}^{-1}$ ) obtained was similar to results of hill forest of Parbat (314.59 ton ha ${ }^{-1}$ ) (Sharma, 2009). Adhikaree (2005) reported that in mid-hill regions of Nepal, the average tree biomass range from 7.78 to 571.10 which roughly accounted to the per hectare carbon storage from 3.89 to 285.55 ton ha ${ }^{-1}$. This finding is also in agreement with the present results. Shrestha (2009) also determined the carbon sequestration of Schima-Castanopsis forest of Palpa district to be 178.52 ton ha $^{-1}$. The species-wise total tree biomass was reported highest for Schima wallichii and Alnus nepalensis. Lagerstroemia parviflora, Shorea robusta were subsequent tree species. In the present study, the species-wise variation in total tree biomass can be attributed to the variation in size of the trees (DBH), age (young or old), edaphic factors and tree wood density.

From the present study, the total biomass loss in the Jure landslide area was 15,336 tons in which the tree species like Schima wallichii (5,788 tons), Alnus nepalensis (5068 tons) have been largely destroyed. In Nepal, due to landslide, $33.20 \mathrm{~km}^{2}$ (3320 ha) area of open forest type was lost (CDESTU, 2015). Therefore, considering the present landslide area as the open forest type, the total biomass lost by landslide in 2015 can be estimated to be $7,17,120$ tons which equals to $14,34,240$ tons of $\mathrm{CO}_{2}$ equivalents. The carbon in coarse woody debris from tree mortality and damage is not immediately respired to the atmosphere. However, its pulse may largely represent committed future $\mathrm{CO}_{2}$ emissions. Thus, elevated forest tree mortality would result higher ecosystem respiration and a potentially important positive feedback with elevated atmospheric $\mathrm{CO}_{2}$ (Chambers et al., 2007).

\section{CONCLUSION}

In the Jure landslide, Schima wallichii, Alnus nepalensis, Terminalia tomentosa, Shorea robusta and Phyllanthus emblica were the major species lost. The landslide has caused considerable loss of tree biomass with substantial carbon dioxide emissions. Thus, to reduce carbon emissions, the mitigation of landslide seems relevant in the Nepalese context. Moreover, Nepal being highly vulnerable to landslide, the indirect measure used in this study could be applied for the estimation of biomass loss due to landslide across the country.

\section{ACKNOWLEDGEMENTS}

We express sincere gratitude to Strengthening Disaster Risk Management in Academia (SDRMA), United Nations Development Programme (UNDP) and Central Department of Environmental Science (CDES), Tribhuvan University (TU) for providing grant to conduct the research. We are also thankful to Mr. Saroj Pokhrel, Mr. Kapil Silwal, Ms. Muna Neupane and Ms. Sanju Ghimire for immense support in the field work.

\section{REFERENCES}

Adhikaree, K. 2005. Estimating Carbon Dynamics in a Nepalese Community Forest, (M.Sc. Thesis), Central Department of Environmental Science, Kirtipur, Kathmandu, Nepal.

Bista, M.S., Adhikari, M.K. and Rajbhandari, K.R. (eds.). 2001. Flowering plants of Nepal. (Phanerogams). Department of Plant Resources National Herbarium and Plant Laboratories, Godavary, Lalitpur, Nepal.

Brown, S., Gillespie, A.J. and Lugo, A.E. 1989. Biomass methods for tropical forest with applications to forest inventory data. Forest science 35: 881-902.

CDES-TU. 2015. Pre-earthquake nationwide landslide inventory of Nepal 2015. 
Strengthening Disaster Risk Management in Academia, Central Department of Environmental Science, Tribhuvan Univeristy and United Nations Development Programme, Kathmandu.

Chambers, J.Q., Fisher, J.I., Zeng, H., Chapman, L.E., Baker, D.B. and Hurtt, G.C. 2007. Hurricane Katrina's carbon footprint on U.S. gulf coast forests. Science 318: 1107.

Chave, J., Andalo C., Brown, S., Cairns, M.A., Chambers, J.Q., Eamus, D., et al. 2005. Tree allometry and improved estimation of carbon Stocks and balance in tropical forests. Oecologia 145: 87-99.

DPNeT. 2014. A report on field visit of Sunkoshi/Bhotekoshi landslide affected area. Disaster Preparedness Network-Nepal. http://www.dpnet.org.np/docs/reportManage ment.pdf. Retrieved on 10th September 2014.

ICMOD. 2014. Rapid field investigation: Jure landslide site, Jure, Sindhupalchowk. International Centre for Integrated Mountain Development. Lalitpur, Nepal.

Mac-Dicken, K.G. 1997. A guide to monitoring carbon storage in forestry and agro forestry projects. Winrock International Institute for Agriculture Development. Arlington, USA, pp.87.

Masera, O., Garza-Caligaris, J.F., Kanninen, M., Karjalainen, T., Liski, J., Nabuurs, G.J., et al. 2003. Modeling Carbon Sequestration in Afforestation, Agroforestry, and Forest Management Projects: the CO2FIX V.2 Approach. Ecological Modeling 164: 177199.

MoFSC. 2010. Forest carbon inventory, 2067. Government of Nepal, Ministry of Forest and Soil Conservation. Kathmandu, Nepal.

MoHA and DPNeT. 2015. Nepal disaster report, 2015. Government of Nepal, Ministry of Home Affairs and Disaster Preparedness Network. Kathmandu, Nepal.

MoI. 2014. Report on Jure Landslide, Mankha VDC, Sindhupalchowk District. Government of Nepal. Ministry of Irrigation.
Pandey, S. and Bajracharya, S.B. 2010.Vegetation composition and biomass production on community forest in Sikre VDC adjoining Shivapuri National Park, Kathmandu. Nepal Journal of Science and Technology 11: 133138.

Pearson, T., Brown, S. and Birdsey, R. 2007. Measurement Guidelines for the Sequestration of Forest Carbon. General Technical Report, NRS-18. Northern Research Station, Department of Agriculture, USA, pp. 47.

Restrepo, C., Vitousek, P. and Neville, P. 2003. Landslides significantly alter land cover and the distribution of biomass: an example from the Ninole ridges of Hawaii. Plant Ecology 166: 131. doi:10.1023/A:1023225419111.

Sharma, S. 2009. Carbon Sequestration Potential of Shorea robusta in Parbat District, Nepal: A Case Study from Samikot Community Forest. (B.Sc. Thesis) Institute of Forest, Tribhuvan University, Pokhara, Nepal.

Shrestha, B.P. 2008. An Analytical Study of Carbon Sequestration in Three Different Forest Types of Mid-Hills of Nepal: A Case from Palpa District. (M.Sc. Thesis) Institute of Forest, Tribhuvan University, Pokhara. Nepal.

Shrestha, B.P. 2009. Carbon sequestration in Schima-Castanopsis forest: A case study from Palpa district. A Journal of Environment and Biodiversity 7(1): 34-40.

Shrestha, K. 1998. Dictionary of Nepalese Plant Names. Mandala Book Point. Nepal.

Stern, N. 2007. The economics of climate change: The Stern Review. Cambridge, UK: Cambridge University Press.

Subedi, B. P., Pandey, S. S., Pandey, A., Rana E. B., Bhattarai S., Banskota T. R., et al. 2010. Guidelines for measuring carbon stocks in community managed forests. ANSAB, ICIMOD, FECOFUN, NORAD, pp. 18 .

Zobel, D., Jha, P., Behan, M. and Yadav, U. 1987. A practical manual for Ecology. Ratna Book Distributors, Kathmandu, Nepal, pp.149. 